\title{
The Worst of Health: LaW and Policy at the INTERSECTION OF HEALTH \& IMMIGRATION
}

\author{
WENDY E. PARMET*
}

This symposium, The Intersection of Immigration Law and Health Policy, could not be timelier. Almost every day since President Trump's inauguration, the news has brought yet another story about immigration and health: we hear about children dying while in the custody of the border patrol ${ }^{1}$ and about the long-term health effects of children who were separated from their parents at the border. $^{2}$ We read about immigrant minors being denied access to reproductive health services, ${ }^{3}$ and about children being stopped by Immigration and Customs Enforcement ("ICE") on their way for emergency surgery. ${ }^{4}$ Physicians report that fearful patients are failing to show up for their medical appointments, ${ }^{5}$ and

* JD, Harvard Law School; BA Cornell University. Mathews University Distinguished Professor of Law and Professor of Public Policy \& Urban Affairs, Northeastern University. Many thanks are owed to Meagan Antonellis, Gabrielle Ramussen and Genna Selesnick for their excellent research help.

1. Maria Sacchetti \& Robert Moore, After $2^{\text {nd }}$ Child Dies in U.S. Custody, Nielsen Expands Medical Screenings, Will Head to Border, WASH. Post (Dec. 26, 2018), https://www. washingtonpost.com/local/immigration/2018/12/26/e7b262d4-0926-11 e9-85b641c0fe0c5b8f_story.html?utm_term=.7cf0df273ba3 [https://perma.cc/VAY8-SK4D].

2. Shadi Houshyar, Family Separation is Harmful to Children's Health, FAMILIES USA (June 2018), https://familiesusa.org/product/family-separation-harmful-children $\% \mathrm{E} 2 \% 80 \% 99 \mathrm{~s}$ health [https://perma.cc/Y26K-F5HL]. Separation from a parent can have dire consequences on a child's health. "In the short-term, children may exhibit loss of appetite, difficulty sleeping, regressive behaviors, and physical symptoms such as stomachaches and detachment - all common signs of post-traumatic stress disorder in young children. In the longer term, family separation can have negative impacts on both the emotional and physical health and well-being of separated parents and children.” Id., see also Samantha Artiga \& Barbara Lyons, Family Consequences of Detention/Deportation: Effects on Finances, Health, and Well-Being, Henry J. KaISER FAm. Found. (Sept. 18, 2018), https://www.kff.org/disparities-policy/issue-brief/family-consequencesof-detention-deportation-effects-on-finances-health-and-well-being/ [https://perma.cc/8J6Q-AQ95].

3. See, e.g., Supreme Court Issues Decision in Jane Doe Abortion Case, ACLU (June 4, 2018), https://www.aclu.org/news/supreme-court-issues-decision-jane-doe-abortion-case [https://perma.cc/KXS9-5UJX].

4. See, e.g., Barbara Campbell, Girl Detained by Border Patrol After Emergency Surgery Released to Parents, NAT'L PUB. RADIO (Nov. 3, 2017, 8:06 PM), https://www.npr.org/ sections/thetwo-way/2017/11/03/562003841/girl-detained-by-border-patrol-after-emergencysurgery-is-released-to-parents [https://perma.cc/69SP-JL6T].

5. See Jan Hoffman, Sick and Afraid, Some Immigrants Forgo Medical Care, N.Y. Times (June 26, 2017), https://www.nytimes.com/2017/06/26/health/undocumented-immigrants-healthcare.html [https://perma.cc/5JKN-S63H]; see also Ike Swetlitz, Immigrants, Fearing Trump's Deportation Policies, Avoid Doctor Visits, STAT (Feb. 24, 2017), https:/www.statnews.com/ 2017/02/24/immigrants-doctors-medical-care/ [https://perma.cc/Y47G-W8R7]; Barrett Newkirk, 'I Can't Imagine the Fear.' Threat of Deportation is Keeping Immigrant Patients Away from California Medical Clinics, DESERT Sun (Apr. 18, 2017), https://www.desertsun.com/story/ 
researchers report that immigrants have refused to enroll their infants in child nutrition programs for fear that doing so could lead to their own deportation. ${ }^{6}$ Hospitals and other health care providers worry about workers, whose ability to remain employed may be threatened by the possible termination of $\mathrm{DACA}^{7}{ }^{7}$ or who may be unable to come to this country and provide care because of the travel ban or cut backs on visas. ${ }^{8}$ Meanwhile the Administration has proposed new proposed public charge regulations, which if promulgated, may cause millions of lawfully present immigrants to forego a broad array of programs that support health, including Medicaid and food stamps. ${ }^{9}$

All of these incidents, and many more, illustrate that when nativist immigration policy meets health law, health policy and public health tend to suffer. ${ }^{10}$ The health care system covers fewer people, while becoming costlier and less efficient. ${ }^{11}$ Public health is also jeopardized as punitive and futile efforts to keep diseases out by excluding or punishing newcomers replace evidence-based public health solutions. ${ }^{12}$ More subtly, when immigration and health policy meet, we lose sight of why the health policy exists in the first place is lost. ${ }^{13}$

This essay explores these issues, examining why and how laws and policies at the intersection of health and immigration are frequently problematic for both health policy and public health. Part I begins by noting that the troubling relationship between immigration and health law is both longstanding and

news/health/2017/04/17/immigration-fears-health-coachella/304874001/ [https://perma.cc/WD4RWS3G].

6. Study: Following 10-Year Gains, SNAP Participation Among Immigrant Families Dropped in 2018, Am. Pub. Health Ass'N (Nov. 12, 2018), https://www.apha.org/news-and$\mathrm{media} / \mathrm{news}-\mathrm{releases/apha-news-releases/2018/annual-meeting-snap-participation}$ [https://perma.cc/7HHK-7WZ8].

7. See Debra F. Weinstein \& Fidencio Saldana, DACA and the Dream of Becoming a Physician, 377 New ENG. J. Med. 1913, 1913 (2017).

8. See What do Immigrant Doctor's Bring to America?, The Immigrant Doctors PROJECT, https://immigrantdoctors.org [https://perma.cc/KN34-22M2].

9. Samantha Artiga, Rachel Garfield, \& Anthony Damico, Estimated Impacts of the Proposed Public Charge Rule on Immigrants and Medicaid, Henry J. KAISER FAM. Found. (Oct. 11, 2018), https://www.kff.org/disparities-policy/issue-brief/estimated-impacts-of-the-proposedpublic-charge-rule-on-immigrants-and-medicaid/ [https://perma.cc/TZ5X-9R7L]. See infra text accompanying notes 106-44, for a further discussion.

10. My co-author Patricia Illingworth and I explored these issues more fully in our book, THE Health of Newcomers: Immigration, Health Policy, and the CASE for Global Solidarity (2017). Much of the discussion that follows is based on arguments that are developed more fully in the book.

11. See infra text accompanying notes 59-81.

12. See, e.g., Angela Perone, From Punitive to Proactive: An Alternative Approach for Responding to HIV Criminalization that Departs from Penalizing Marginalized Communities, 24 HASTings Women's L.J. 363, 379-83 (2013).

13. See infra text accompanying notes $145-60$. 
international in scope. ${ }^{14}$ Parts II and III explore the impact of the interjection of immigration policy into health law, discussing in Part II how it adds to the complexity and inefficiency of the health care system ${ }^{15}$ and in Part III, how it harms public health. ${ }^{16}$ Part IV elucidates those claims further by exploring the potential health impact of the proposed public charge regulations. ${ }^{17}$ Part V concludes by arguing that the battles over immigration and health both reflect and shed light on deeply-seated divisions over the nature of community, the scope of solidarity, and the underlying rationale for health policy and law. ${ }^{18} \mathrm{I}$ also argue that health laws' treatment of immigrants forces us to consider the basic rationales for health law. That inquiry offers the possibility of a richer and deeper appreciation of the ethical foundations for health law.

\section{AN ENDURING AND UNIVERSAL TEMPEST}

The contentious relationship between immigration and health policy did not begin with the Trump Administration. The belief that noncitizens (documented and undocumented) are undeserving of publicly-supported health programs and create a threat to the public's health has long influenced U.S. health policy. Space permits only a brief survey.

In the nineteenth and early twentieth centuries, immigrants to the United States were frequently blamed for epidemics, and were routinely subjected to excessively harsh, punitive, and largely ineffective public health policies, such as quarantine. ${ }^{19}$ Perhaps the best-known, but not the only, example of this was San Francisco's treatment of Chinese-Americans and Chinese immigrants when bubonic plague struck the city in $1900 .^{20}$ Rather than viewing residents of Chinatown as victims of the plague, city and federal health officials treated them as dangerous vectors, or sources of contagion, and ordered Chinese-Americans and other residents of Asian descent to be inoculated with an experimental vaccine, known as the Haffkine prophylactic. ${ }^{21}$ When that order was struck down by a federal court as violating the Fourteenth Amendment, officials responded by imposing a quarantine, that was enforced only against individuals of Asian ancestry. This led a Chinese immigrant, Jew Ho, to bring yet another lawsuit. Once again the order was struck down as "unreasonable, unjust, and

14. See infra text accompanying notes 19-57.

15. See infra text accompanying notes 58-81.

16. See infra text accompanying notes 82-105.

17. See infra text accompanying notes 106-44.

18. See infra text accompanying notes 145-60.

19. ILlingWORTH \& PARMET, supra note 10, at 52-61.

20. For a fuller discussion, see, e.g., Marilyn Chase, The Barbary Plague: The Black Death in Victorian San Francisco passim (2004); Nayan Shah, Contagious Divides: EPidemics AND RACE in SAN Francisco's Chinatown 120-57 (2001).

21. See Wong Wai v. Williamson, 103 F. 1, 6 (C.C.N.D. Cal. 1900). The incident also reveals the racist roots of many anti-immigrant policies. 
oppressive." 22

San Francisco was not the only jurisdiction to blame immigrants for an epidemic. Indeed, many of the most famous targets of coercive public health measures, from Henning Jacobson, who was criminally charged for refusing to be vaccinated for smallpox, ${ }^{23}$ to Mary Mallon, a.k.a. Typhoid Mary, who was quarantined for life for spreading typhoid fever ${ }^{24}$ were immigrants. This is no coincidence. Throughout U.S. history, immigrants were viewed as inherently dangerous sources of contagion who had to be subjected to highly coercive measures in order to protect the health of native-born citizens.

The belief that immigrants are the source of disease is not only evident in the disparate application of coercive public health measures to immigrants, it is also apparent in our immigration laws. From their very inception, U.S. immigration laws tried to keep out immigrants who were thought to carry dangerous diseases or burden the nation with their ill health. Indeed, even before Congress regulated immigration, the states used their police powers to inspect passengers for disease and restrict entry of immigrants who were considered dangerous sources of infection. ${ }^{25}$ These practices were upheld by the Supreme Court in 1837 in Mayor of New York v. Miln. ${ }^{26}$ Describing the federal immigration power in 1889, the Supreme Court stated, "there has never been any question as to the power to exclude [immigrants]. The power is constantly exercised; its existence is involved in the right of self-preservation." ${ }^{27}$ A few years later, the Supreme Court affirmed a Louisiana regulation that barred healthy immigrants from entering parts of the state in which there were communicable diseases. ${ }^{28}$ As the state saw it, immigrants added "fuel to the flame." 29

Likewise, from its inception, federal immigration law attempted to protect public health by keeping out immigrants who were viewed as either dangerous to the public's health or unproductive due to their own ill health. The Immigration

22. Jew Ho v. Williamson, 103 F. 10, 26 (C.C.N.D. Cal. 1900).

23. Jacobson v. Massachusetts, 197 U.S. 11, 13 (1905); Wendy E. Parmet, Richard A. Goodman, \& Amy Farberal, Perspective: Individual Rights Versus the Public's Health-100 Years After Jacobson v. Massachusetts, 352 New ENG. J. MeD. 652 (2005).

24. Judith Walzer Leavitt, Typhoid Mary: Captive to the Public's Health passim (10th ed. 1997).

25. IlLingWORTH \& PARMET, supra note 10, at 32-33.

26. See generally, New York v. Miln, 36 U.S. 102 (1837). As the federal government asserted greater authority over immigration and quarantine at the border, the Court came to see these issues as falling within the power of the federal government. See, e.g., Hines v. Davidowitz, 312 U.S. 52, 62 (1941) ("That the supremacy of the national power in the general field of foreign affairs, including power over immigration, naturalization and deportation, is made clear by the Constitution, was pointed out by authors of The Federalist in 1787, and has since been given continuous recognition by this Court.”).

27. Chae Chan Ping v. United States, 130 U.S. 581, 608 (1889).

28. Compagnie Francaise de Navigation a Vapeur v. La. Board of Health, 186 U.S. 380, 397 (1902)

29. Id. at 399. 
Act of 1882 excluded from admission into the U.S. "any convict, lunatic, idiot, or any person unable to take care of himself or herself without becoming a public charge." ${ }^{30}$ In 1891, Congress barred those "suffering from a loathsome or a dangerous contagious disease," as well as "insane persons, paupers or persons likely to become a public charge." ${ }^{31}$ In 1893, Congress authorized federal officials to conduct overseas medical examinations. ${ }^{32}$ In the years that followed, thousands of immigrants were denied the right to travel to the United States as a result of these inspections. For example, in 1907, more than 35,000 immigrants were denied passage to the U.S. from Italy alone. ${ }^{33}$ Those who arrived faced humiliating, publicly-visible medical inspections at ports of entry, including at Ellis and Angel Islands. ${ }^{34}$ During these examinations, inspectors relied on manuals that were heavily infused with explicit racial assumptions about the health and emotional character of immigrant populations. ${ }^{35}$

In hindsight, it is hard to see how these measures preserved the nation's health. Few immigrants were actually excluded on health-related grounds; moreover, the examinations were poorly suited to prevent the spread of tuberculosis, influenza, or the other infectious diseases that were most prevalent and dangerous during the early twentieth century. ${ }^{36}$ Instead, examiners focused on trachoma, which was most prevalent in parts of the country that had few immigrants. ${ }^{37}$ Rather than preserve the public's health, the examinations were designed to keep out those who were thought to be unproductive, while reaffirming to all immigrants their lowly and tenuous status in their new country.

The conflation of immigration and health policy, and the erroneous perception that immigrants pose a unique danger to the public's health, has not disappeared with the advent of modern public health science. In arguing for money to build a wall at the southern border, President Trump claimed, "People with tremendous medical difficulty and medical problems are pouring in, and in many cases it's contagious. ${ }^{38}$ Likewise, federal immigration law continues to confuse immigration control with communicable disease control. For example, the Immigration and Naturalization Act (INA) excludes immigrants with a "communicable disease of public health significance." 39 Although that term is

30. Immigr. Act $\S 2$, ch. 376, 22 Stat. 214 (1882).

31. Act of Mar. 3, 1891, ch. 551, § 1, 26 Stat. 1084 (1891).

32. Act of Mar. 3, 1893, ch. 206, § 1, 27 Stat. 569 (1893).

33. Amy L. Fairchild, Science at the Borders: Immigrant MedicAl InSPECtion AND THE SHAPING OF THE MODERN INDUSTRIAl LABOR ForCE 59 (2003).

34. Id. at $86-98$.

35. Id. at 160-89, 194-209.

36. ILLINGWORTH \& PARMET, supra note 10, at 36.

37. Id. at 35 .

38. Philip Bump, Trump's Arguments for Necessity of Border Wall Have Already Been Broadly Debunked, WASH. Post (Dec. 11, 2018), https:/www.washingtonpost.com/politics/ 2018/12/11/trumps-arguments-necessity-border-wall-have-already-been-broadlydebunked/?utm_term=.6b440e812164/[https://perma.cc/TQH4-H8VA].

39. Immigration and Nationality Act, 8 U.S.C. $\S 1182(a)(1)(A)(i)(2013)$. 
currently applied narrowly to relatively rare diseases that are not already endemic within the U.S., such as Ebola, the law gives the President sole discretion to determine the list of excludable diseases. ${ }^{40}$ In addition, the INA continues to exclude immigrants (with certain exceptions) who are found likely to become a public charge..$^{41}$ In making that determination, the Act directs officials to consider an immigrant's health status. ${ }^{42}$

Perhaps the most disturbing example of the conflation of public health policy and immigration in the modern era concerned the treatment of HIV positive Haitian refugees in the 1990s. Long after HIV was endemic in the U.S., and thus the nation could not be kept free of AIDS by keeping immigrants out, and well after health officials had warned that discrimination and stigmatization could hamper prevention efforts, ${ }^{43}$ Congress barred noncitizens with HIV from visiting or immigrating to the U.S., and the federal government quarantined HIV positive refugees from Haiti at Guantanamo Bay, $\mathrm{Cuba}^{44}{ }^{44}$ an action that presaged the later use of Guantanamo as a prevention detention, or quarantine, camp for suspected terrorists.

Anti-immigrant sentiment has also influenced immigrants' access to health programs. For example, in 1994, following a campaign that claimed that immigrants were a drain on the state's health care system, California voters enacted Proposition 187, which barred undocumented immigrants from accessing health public benefits, and required health care workers, among others, to report those they suspected of being undocumented. ${ }^{45}$ Although Proposition 187 was quickly enjoined by the courts, and never went into effect, it paved the way for the 1996 federal Personal Responsibility and Work Opportunity Reconciliation Act (PRWORA), which established significant limits on the eligibility of immigrants, both undocumented and lawfully present, to federally-funded health

40. See U.S. Citizenship \& Immigration Servs.,Pol'y Manual, Communicable Disease of Public Health Significance (2018), https://www.uscis.gov/policymanual/HTML/ PolicyManual-Volume8-PartB-Chapter6.html [https://perma.cc/ST8C-M6CD] (noting that the President may add to the HHS designated list of relevant communicable diseases via Executive Order).

41. Immigration and Nationality Act, 8 U.S.C. $§ 1182(a)(4)(A)(2013)$.

42. Id. See infra text accompanying notes 106-44, for a further discussion of the public charge exclusion.

43. Presidential Commission on the Human Immunodeficiency Virus Epidemic, REPORT OF THE PRESIDENTIAL COMMISSION ON THE HuMAN IMMUNODEFICIENCY VIRUS EPIDEMIC 128-30 (1988), https://files.eric.ed.gov/fulltext/ED299531.pdf [https://perma.cc/6HVR-HZZR].

44. Lynne Duke, Haitian Refugees with HIV Remain in Limbo as Asylum Claims Stall, WASH. Post (Aug. 7, 1992), https://www.washingtonpost.com/archive/politics/1992/08/07/haitianrefugees-with-hiv-remain-in-limbo-as-asylum-claims-stall/84203872-0b08-4306-9e0ec4e6c0055327/?utm_term=.709800567a9f [https://perma.cc/F25P-DV6Z].

45. CA's Anti-Immigrant Proposition 187 is Voided, Ending State's Five-Year Battle with ACLU, Rights Groups, ACLU (July 29, 1999), https://www.aclu.org/news/cas-anti-immigrantproposition-187-voided-ending-states-five-year-battle-aclu-rights-groups [https://perma.cc/AM3JT3QF]. 
benefits. $^{46}$

Then came the 2008 financial crisis. Faced with budgetary pressures, states across the nation moved to further cut health benefits for immigrants. ${ }^{47}$ For example, Massachusetts, which extolled its adoption of so-called universal health care in $2006,{ }^{48}$ cut back on that promise, cutting classes of legal immigrants who were barred from federally-funded benefits from the state's forerunner of what became the ACA exchanges. ${ }^{49}$

Perhaps most importantly, in the summer of 2009, when the bill that became the Affordable Care Act (ACA) was being debated across the country, its opponents rallied around the erroneous claim that it would cover undocumented immigrants. ${ }^{50}$ In response, in September 2009, President Obama promised in a joint session of Congress that his health care plan would do no such thing. ${ }^{51}$ Foreshadowing the current heated state of political discourse, Republican Representative Joe Wilson from South Carolina shouted over the President, "You lie." ${ }^{52}$ What was most remarkable about this incident was not Representative Wilson's breach of decorum, but the strength of the immigration-focused opposition to health reform. In effect, the ACA's opponents seemed to believe that denying immigrants access to care was even more important than ensuring that citizens had access to care. ${ }^{53}$

This vehemence, which anticipated President Trump's nationalist agenda, is also evident in other parts of the world. As in the U.S., immigrants in Europe are blamed for diseases and derided as drains on publicly-funded health programs. To give but a few examples, supporters of Brexit believed that immigration had caused a decline in the quality of health care services. ${ }^{54}$ In Poland, former Prime

46. Personal Responsibility and Work Opportunity Reconciliation Act of 1996, 110 Stat. 2105. See infra text accompanying notes 60-70, for a further discussion.

47. See, e.g., Hong Pham v. Starkowski, 16 A.3d 635, 637 (Conn. 2011).

48. 2006 MASs. ACts Ch. 58 (codified in various sections of Mass. GEN. LAws (2008)).

49. MASs. Gen. Laws ch. 65, § 31(a) (2009),). invalidated by Finch v. Commonwealth Health Ins. Connector Auth., 959 N.E.2d 970, 984 (Mass. 2012).

50. Julia Preston, Health Care Debate Focuses on Legal Immigrants, N.Y. Times (Nov. 3, 2009), https://www.nytimes.com/2009/11/04/health/policy/04immig.html [https://perma.cc/65P6BTMK] ("The debate over health care for illegal immigrants continues to percolate in Congress despite the Obama administration's efforts to put it to rest, with lawmakers in both houses also wrangling over how much coverage to provide for immigrants who have settled in the country legally.").

51. Rep. Wilson Shouts, 'You Lie' to Obama During Speech, CNN (Sept. 10, 2009), http://www.cnn.com/2009/POLITICS/09/09/joe.wilson/ [https://perma.cc/U6NV-5NQ9].

52. Id.

53. Also relevant to the history is the collapse of a bipartisan immigration reform effort in Congress in 2014. See, e.g., Why Immigration Reform Died in Congress, NBC News (June 30, 2014), https://www.nbcnews.com/politics/first-read/why-immigration-reform-died-congressn145276 [https://perma.cc/7B79-C22B].

54. Public Wrong on Key Facts Around Brexit and Impact of EU Membership, New Study Finds, KING'S COLLEGE LONDON (Oct. 28, 2018), https://www.kcl.ac.uk/sspp/policy-institute/news/ 
Minister and current leader of the Law and Justice Party, Jaroslaw Kaczyński, has warned that migrants bring to Europe "very dangerous diseases long absent from Europe." ${ }^{55}$

Moreover, all European nations deny some classes of immigrants access to their national health insurance programs; and as migration has increased in the last several years, many European nations have cut back on programs that cover migrants. ${ }^{56}$ Indeed, once we turn our eyes to the intersection of immigration and health, we can see that no Western nation has truly universal health coverage. ${ }^{57}$ All exclude some noncitizen immigrants from some benefits. To understand why that is so, and to appreciate what happens when immigration and health policy meet, we need to look beyond today's headlines, and not fool ourselves into thinking that today's problems are simply the result of a single election.

\section{UNDERMINING HEALTH POLICY}

It is easy to see how the laws and policies described above adversely affect the health and well-being of immigrants. What is less obvious, but no less important, is that these laws and policies add to the complexity, cost, and inefficiency of our health care system. In part, this is because as a nation we are deeply conflicted about immigrants' place in our health care system. Time after time, anti-immigrant sentiment has led to the enactment of laws that seek to limit access by both undocumented and authorized noncitizen immigrants to that system. ${ }^{58}$ But almost as often, the recognition that immigrants are members of our community, and that their health affects the health of citizens, has prompted the passage of other laws that create exceptions to the restrictive policies. ${ }^{59}$ The result is a hodgepodge of confusing and conflicting laws that make little sense from almost any policy perspective.

Consider PRWORA. It deemed certain categories of noncitizens, including undocumented immigrants and travelers, as "unqualified" for most federallyfunded benefits, including Medicaid and the Children's Health Insurance Program

newsrecords/2018/public-wrong-on-key-facts-around-brexit-and-impact-of-eu-membership-newstudy-finds.aspx [https://perma.cc/HQ3Y-U93R].

55. Jan Cienski, Migrants Carry 'Parasites and Protozoa,' Warns Polish Opposition Leader, Politico (Oct. 14, 2015, 6:21 PM), https://www.politico.eu/article/migrants-asylum-polandkaczynski-election/ [https://perma.cc/C9HV-T7QT].

56. See, e.g., Abby Young-Powell, Austria Plans to Cut Benefits for Non-German Speaking Immigrants, TELEGRAPH (May 29, 2018, 5:48 PM), https://www.telegraph.co.uk/news/ 2018/05/29/austria-plans-cut-benefits-non-german-speaking-immigrants/ [https://perma.cc/D6KD5RC7].

57. Thailand, however, appears to have truly universal coverage. Wudan Yan, Only One Country Offers Universal Health Care to All Migrants, NAT'L PuB. RAdio (Mar. 31, 2016, 10:19 AM), https://www.npr.org/sections/goatsandsoda/2016/03/31/469608931/only-one-country-offersuniversal-health-care-to-undocumented-migrants [https://perma.cc/G9DE-RWPA].

58. See supra text accompanying notes $45-53$.

59. See infra text accompanying notes 63-75. 
(CHIP) ${ }^{60}$ It also established a five year bar during which time most classes of socalled "qualified immigrants," not including refugees and certain other groups granted humanitarian treatment, are ineligible for such programs ${ }^{61}$ Whether those exclusions were good for health policy, I will leave for another day. ${ }^{62}$

For present purposes, what is interesting is that PRWORA's restrictions are not all-encompassing. First, they do not apply to public health programs, such as vaccination clinics. ${ }^{63}$ Thus, despite its aim of denying certain noncitizens access to federal benefits, Congress recognized the importance of extending communicable disease prevention programs even to newcomers who were otherwise deemed unqualified for federal benefits. Likewise, PRWORA does not bar undocumented immigrants from receiving so-called Emergency Medicaid, ${ }^{64}$ which provides reimbursement for hospitals that provide emergency medical treatment, as required by the Emergency Medical Treatment and Active Labor Act (EMTALA). ${ }^{65}$ This is in part because PRWORA kept in place EMTALA's requirement that hospitals with emergency departments examine and stabilize patients who present with emergencies. ${ }^{66}$ Congress was thus unwilling, despite its desire to deny immigrants public benefits, to see people with emergencies turned away to die on the streets. Nor did Congress want to force hospitals to bear all of the costs of treating immigrants who PRWORA left ineligible for federal health insurance programs. Yet, the compromise that resulted from PRWORA's efforts to limit immigrants' access to benefits, while providing some access to emergency care, means that unqualified immigrants, as well as many qualified immigrants within PRWORA's five year bar, are forced to receive much of their care in the most expensive setting, the emergency room. ${ }^{67}$ As a result, in some states, dialysis patients are forced to wait until their condition becomes critical in order to be dialyzed and cancer patients are left without access to ambulatory treatments and care. ${ }^{68}$ This is bad for their health and more expensive for the

60. 8 U.S.C. $\S \S 1611,1621,1641$ (2012).

61. 8 U.S.C. $\S 1613$ (2012).

62. I have criticized PRWORA's exclusions elsewhere. See Wendy E. Parmet, Who's In?: Immigrants and Healthcare, in OXFORD HANDBOOK OF U.S. HeAlth 1033, 1041-50 (I. Glenn Cohen, Allison K. Hoffman \& William M. Sage eds., 2017).

63. 8 U.S.C. $\S \S 1611(\mathrm{~b})(1)(\mathrm{C}), 1621(\mathrm{~b})(3)(2012)$.

64. 8 U.S.C. $\S \S 1611(\mathrm{~b})(1)(A), 1621(b)(1)$ (2012). (However, this exception excludes emergency organ transplants.).

65. 42 U.S.C. $\$ \S 1395 \mathrm{cc}, 1395 \mathrm{dd}(2012)$.

66. 42 U.S.C. $\S 1395 \mathrm{dd}(2012)$.

67. IllingWORTH \& PARMET, supra note 10, at 83-96. It should be noted, however, that many uninsured immigrants receive care in federally-funded community health centers. See Steven P. Wallace et al., Community Health Centers Play a Critical Role in Caring for the Remaining Uninsured in the Affordable Care Act Era, UCLA Ctr. for Health Pol'y Res: Health Pol'y BRIEF (Oct. 2016), http://healthpolicy.ucla.edu/publications/Documents/PDF/2016/FQHC_PBoct2016.pdf [https://perma.cc/T84S-2JLQ]..

68. ILLINGWORTH \& PARMET, supra note 10, at 83-96. 
government. ${ }^{69}$ How this makes sense from either a health care or health policy perspective is hard to see.

Congress's ambivalence about noncitizens' eligibility for publicly-supported health care is also evident in the fact that PRWORA allows states to expand or narrow immigrants' eligibility to state-funded programs. ${ }^{70}$ Subsequent federal laws have given states even greater leeway to expand coverage. For example, Sec. 214 of the Children's Health Insurance Program Reauthorization Act, permits states to cover lawfully present pregnant women and children, even if they are PRWORA-ineligible. ${ }^{71}$ As of 2018, thirty three states had elected to cover children and twenty five had chosen to cover pregnant women. ${ }^{72}$

The ACA added to the intricacy by utilizing different criteria, "lawfully present," to determine if immigrants were eligible for its own benefits. ${ }^{73}$ The ACA also allowed lawfully present noncitizens, with income levels otherwise below those required of citizens, to buy insurance on the exchanges ${ }^{74}$ This provision was an attempt to mitigate the fact that PRWORA bars many noncitizens with low incomes from enrolling in Medicaid. ${ }^{75}$

These exclusions and exceptions to the exclusions underscore a simple point: immigration policies have added to the complexity and fragmentation of our already complicated and disparate health care system. Indeed, while it is common to note the fragmentation that exists between Medicare and the fifty plus Medicaid programs, the overlay of immigration law adds to that division as many states run Medicaid-like programs for immigrants who, due to PRWORA, are

69. Id.

70. 8 U.S.C. $\S 1621$ (d) (2012) (state authority to provide for eligibility for unqualified noncitizens); 8 U.S.C. $\S 1622$ (2012) (state authority to determine eligibility of qualified noncitizens).

71. 42 U.S.C.A. $§ 1396 b(v)(4)(A)$ (2012). See also, Children's Health Insurance Program Reauthorization Act of 2009, sec. 214, Pub. L. No. 111-3, 123 Stat. 9.

72. Medicaid/CHIP Coverage of Lawfully-Residing Immigrant Children and Pregnant Women, HENRY J. KAISER FAM. FOUND. (Jan. 1, 2018), https://www.kff.org/health-reform/stateindicator/medicaid-chip-coverage-of-lawfully-residing-immigrant-children-and-pregnantwomen $/$ ?currentT imeframe $=0 \&$ sortModel $=\% 7 \mathrm{~B} \% 22$ colld $\% 22: \% 22$ Location $\% 22, \% 22$ sort $\% 22$ : $\% 22$ asc\%22\%7D [https://perma.cc/97MQ-3NHU].

73. Patient Protection and Affordable Care Act of 2010, 42 U.S.C. § 18032(f)(3) (2012).

74. 42 U.S.C. $\$ 18071$ (e) (2012).

75. In enacting the ACA, Congress assumed that citizens with incomes under $100 \%$ of the federal poverty level (FPL) would be eligible for Medicaid under the Medicaid expansion. Many lawfully present noncitizens would not be eligible because of PRWORA. Hence the enactment of different eligibility levels was designed to permit low income noncitizens to access subsidized insurance on the exchanges in lieu of the Medicaid that PRWORA denied them. ILLINGWORTH \& PARMET, supra note 10, at 82-83. When the Supreme Court ruled that the Medicaid expansion was voluntary for the states in Nat'l Fed. Indep. Bus. v. Sebelius, 567 U.S. 519, 575-86 (2012), citizens in non-expansion states were left with less access to publicly-supported health insurance than lawfully present noncitizens. ILLINGWORTH \& PARMET, supra note 10, at 82. 
ineligible for federal Medicaid. ${ }^{76}$

Yet, despite these state programs, and the many exceptions to the exclusions, significant coverage gaps remain. It therefore should not be surprising that noncitizen immigrants, both documented and undocumented, are less likely to have health insurance than the native-borne population. ${ }^{77}$ Hence federal policies, including the ACA, that have aimed to increase coverage, and reduce uncompensated care, have been limited in their reach in part due to immigrationfocused limitations.

Immigration law may undermine efforts to finance our health care system in other ways. Despite the widely held belief that immigrants burden our health care system, research consistently shows that immigrants on average are younger, healthier, and use fewer health resources than native-born residents. ${ }^{78} \mathrm{~A}$ recent study by Leah Zallman and colleagues found that immigrants pay more in private insurance premiums than they receive in benefits, ${ }^{79}$ and a literature review by Lila Flavin and colleagues found that immigrants are a "net contributor[] to Medicare's trust fund." ${ }^{80}$ Yet, policies designed to restrict immigration and limit the ability of even lawfully-present immigrants from participating in insurance programs, limit their ability to participate in and fund these programs. ${ }^{81}$

In all of these cases, immigration law undercuts whatever policy objectives are otherwise apparent in health law. It also makes already complicated and murky areas of health law even more baroque. Perhaps most importantly, by contradicting health policy objectives, and necessitating ever-more complex exceptions and work-arounds, the insertion of immigration law into health law creates inefficiencies and costs in implementation and compliance.

76. Immigrant Eligibility for Health Care Programs in the United States, NAT'L CONF. OF ST. LEGISLATORS (Oct. 19, 2017), http://www.ncsl.org/research/immigration/immigrant-eligibilityfor-health-care-programs-in-the-united-states.aspx [https://perma.cc/L4NL-K9KL].

77. Jim P. Stimpson \& Fernando A. Wilson, Medicaid Expansion Improved Health Insurance Coverage for Immigrants, but Disparities Persist, 37 Health Aff. 1656, 1660 (2018).

78. E.g., Illingworth \& PARMet, supra note 10, at 89; see also Eran Shor, David Roelfs \& Zoua M. Vang, The "Hispanic Mortality Paradox" Revisited: Meta-Analysis and MetaRegression of Life-Course Differentials in Latin American and Caribbean Immigrants' Mortality, 186 Soc. SCI. \& MED. 20, 22 (2017) (reviewing literature on the healthy migrant effect, especially with regard to immigrants from Latin America and the Caribbean and noting that while immigrants overall enjoy a mortality advantage, immigrant children suffer from an immigrant mortality disadvantage).

79. Leah Zallman et al., Immigrants Pay More in Private Insurance Premiums Than They Receive in Benefits, 37 Health AfF. 1663, 1663 (2018).

80. Lila Flavin et al., Medical Expenditures on and by Immigrant Populations in the United States: A Systematic Review, 48 InT'L J. Health Servs. 601, 616-17 (2018).

81. For a discussion of the public charge regulations, see infra text accompanying notes 10644. 


\section{HARMS TO THE PUBLIC'S HEALTH}

The interjection of immigration policy into health law is also bad for the nation's health. The danger, however, does not arise from the infections that immigrants allegedly bring to the country, as anti-immigrant critics frequently charge. Indeed, for the most part, immigrants are healthier than native born citizens. ${ }^{82}$ And although they do have higher rates of tuberculosis, there is no evidence that they pose a significant risk of spreading that disease to the broader population. ${ }^{83}$ Nor is there any reason to believe that they are more likely to transmit other infectious diseases.

Rather, the public health threats that arise at the intersection between immigration and health derive from policy decisions, including barriers to health coverage, stresses to the health care system, the exacerbation of negative social determinants, the perpetuation of stigma, and the displacement of evidence-based public health interventions with fear-based anti-immigrant policies. Space permits only a brief discussion of each.

As was noted previously, our health laws are riddled with provisions that exclude immigrants from publicly-financed health insurance programs. In part as a result of these exclusions, noncitizen immigrants, especially those who are undocumented, are far less likely to have insurance than native-born citizens. ${ }^{84}$ They are also less likely to have a regular source of care or to utilize preventive care. ${ }^{85}$ This means that although immigrants tend to be healthier than the nativeborn population, ${ }^{86}$ they may be more vulnerable to preventable or controllable diseases. $^{87}$

Pregnant women and children are especially at risk. Studies show that many women without insurance delay or lack access to prenatal care, which can impact the long-term health of their children. ${ }^{88}$ Children may also suffer when their parents have untreated or uncontrolled illnesses. Around 18 million children in the U.S., most of whom are citizens, have at least one immigrant parent. ${ }^{89}$ These

82. See supra note 78 .

83. See Illingworth \& PARMET, supra note 10, at 62-73.

84. Henry J. Kaiser fam. Found.., Health Coverage of Immigrants 1 (2019), http://files.kff.org/attachment/Fact-Sheet-Health-Coverage-for-Immigrants. [https://perma.cc/96KU-D3K9].

85. Frank Otto, Undocumented Immigrants Least Likely to See a Doctor, But Still Healthier Than Other Populations, MED. XPRESS (Sept. 14, 2018), https://medicalxpress.com/news/2018-09undocumented-immigrants-doctor-healthier-populations.html [https://perma.cc/K8AU-EYWM].

86. Id.

87. See, e.g., Cheryl Bettigole, An Uninsured Immigrant Delays Needed Care, 34 Health AFF. 2192, 2195 (2015).

88. Proposed Changes to "Public Charge" Policies for Immigrants: Implications for Health Coverage, Henry J. KAISER FAm. Found. (Sept. 24, 2018), https://www.kff.org/disparitiespolicy/fact-sheet/proposed-changes-to-public-charge-policies-for-immigrants-implications-forhealth-coverage/ [https://perma.cc/8J9C-93SY].

89. Children in U.S. Immigrant Families, Migration PoL'y Inst., https://www. 
children are vulnerable to policies that harm the health of their parents.

Public health is also threatened because health care institutions and health care workers bear the burdens of immigration laws' impact on health care. Safety net hospitals and community health centers are forced to bear more uncompensated costs when their patients are denied access to public programs or dis-enroll due to fear of the immigration consequences that may arise if they seek health care or enroll in publicly-funded insurance programs. Safety-net providers also face extra burdens due to the added complexities that immigration policies have forged onto our health insurance system. In some cases, these extra costs and burdens may lead to fewer services or even hospital closings, to the detriment of all patients in a community. ${ }^{90}$

Public health also suffers when health care workers are forced to worry about their own immigration problems. In 2016, immigrants comprised seventeen percent of the health care workforce. ${ }^{91}$ Cutbacks in H1 visas and the termination of DACA will affect many of these workers, including physicians and nurses. ${ }^{92}$ But less skilled workers - twenty-four percent of whom are immigrants - are especially vulnerable. ${ }^{93}$ For example, about one-quarter of home health aides are foreign born, and a third rely on public benefits. ${ }^{94}$ Policies that increase their immigration risk due to their health or insurance status, or deny them access to health benefits, may make it harder for them to stay healthy and care for their patients. Patients will also suffer, especially in the years to come, as an aging population increases the demand for immigrant workers who may not be there. ${ }^{95}$ In this sense, the policies that are imposed on immigrants rebound to the detriment of the health of citizens.

Policies at the intersection of immigration and health may also jeopardize

migrationpolicy.org/programs/data-hub/charts/children-immigrant-families [https://perma.cc/TJ68F743] (last updated 2017).

90. See Illingworth \& Parmet, supra note 10, at 92; Cindy Mann, Et Al., Medicaid Payments at Risk for Hospitals Under the Public Charge Proposed Rule 4 (Nov. 2018), https:/www.manatt.com/Manatt/media/Media/PDF/White\%20Papers/Medicaid-Payments-at-Riskfor-Hospitals.pdf [https://perma.cc/U42A-FPMW].

91. Szilvia Altorjai \& Jeanne Batalova, Immigrant Health-Care Workers in the United States, MigRATION POL'Y InST. (June 28, 2017), https://www.migrationpolicy.org/article/immigranthealth-care-workers-united-states [https://perma.cc/TM5E-2GB6].

92. Weinstein \& Saldana, supra note 7, at 1913-15; Casey Ross \& Max Blau, US Health Care Relies Heavily on Foreign Workers. Trump's Immigration Ban is Raising Alarms (Jan. 30, 2017), https://www.statnews.com/2017/01/30/trump-immigration-ban-health-workers/ [https://perma.cc/W2JS-RS9C].

93. Altorjai \& Batalova, supra note 91.

94. Wendy E. Parmet \& Elisabeth Ryan, New Dangers for Immigrants and the Health Care System, Health Aff. Blog (Apr. 20, 2018), https://www.healthaffairs.org/do/10.1377/ hblog20180419.892713/full/ [https://perma.cc/QCB9-JXAX].

95. See E. Tammy Kim, Americans Will Struggle to Grow Old at Home, BloomberG BusINESSWEEK (Feb. 9, 2018), https://www.bloomberg.com/news/features/2018-02-09/americanswill-struggle-to-grow-old-at-home. 
public health by increasing the stress on immigrants and their families. Although hospitals are supposedly sensitive institutions, in which ICE will not generally carry out enforcement proceedings, ${ }^{96}$ news reports about immigrants being detained on the way to seeking care, and the broader crackdown on immigrants, has helped to create a climate of fear. Even before the publication of the proposed public charge rule, clinicians reported that immigrant patients were canceling or skipping their appointments ${ }^{97}$ and that children were experiencing increased signs of a wide range of stress-related problems, including depression, anxiety, headaches, stomachaches, and problems sleeping and eating. ${ }^{98}$ Many of the children suffering these consequences are citizens. ${ }^{99}$

Immigration policies also harm public health by increasing the stigma surrounding different diseases. For example, consider the tension that existed for many years between policies that sought to encourage HIV testing and the ban on immigration by individuals who were HIV positive. ${ }^{100}$ While health officials sought to reduce stigma as a way of encouraging HIV testing and controlling the epidemic, immigration-focused policies reinforced stigma by penalizing people for their HIV status. Indeed, the HIV immigration ban even led to a long-running boycott of the U.S. by the International AIDS Conference, and kept many HIV researchers from traveling to and working in the U.S. ${ }^{101}$ Likewise, the INA's bar of entry to drug users and addicts ${ }^{102}$ reinforces the stigma associated with substance use disorders, potentially undermining efforts to destigmatize the problem and increase people's willingness to seek treatment. ${ }^{103}$

The insertion of immigration into public health law may also undermine public health efforts in a more subtle fashion. As long as the public believes that

96. FAQ on Sensitive Locations and Courthouse Arrests, U.S. IMMIGRATION \& CUSTOMS ENFORCEMENT, https://www.ice.gov/ero/enforcement/sensitive-loc [https://perma.cc/V53S-LB82].

97. The Children's Partnership, California Children in Immigrant Families: The Health Provider Perspective, (2018), https://www.childrenspartnership.org/wpcontent/uploads/2018/03/Provider-Survey-Inforgraphic-.pdf [https://perma.cc/K8W4-3RV6].

98. Samantha Artiga, \& Petry Ubri, Living in an Immigrant Family in America: How Fear and Toxic Stress are Affecting Daily Life, Well-Being, \& Health, HenRy J. KAISER FAM. Found. (Dec. 13, 2017), https:/www.kff.org/disparities-policy/issue-brief/living-in-an-immigrant-familyin-america-how-fear-and-toxic-stress-are-affecting-daily-life-well-being-health/ [https://perma.cc/J7TF-WU63].

99. Id.

100. See supra text accompanying notes 44-45.

101. Brett Norman, After 22 Years, AIDS Meeting in D.C., Politico (July 22, 2012, 10:13 PM), https://www.politico.com/story/2012/07/after-22-years-aids-conference-comes-to-dc-078829 [https://perma.cc/PMP6-5DLR] (reporting that the International AIDS Conference was returning to the U.S. after a twenty-two year boycott following the ban on visas to people who were HIV positive).

102. 8 U.S.C. $§ 1182(a)(1)(A)(i v)$ (2012).

103. On the impact of stigma on substance use disorders, see, e.g., Lawrence H. Yang et al., Stigma and Substance Use Disorders: An International Phenomenon, 30 CURRENT OPINION PSYCHIATRY 378, 378 (2017). 
infectious diseases and pandemics are caused by immigrants, it will continue to demand travel and immigration bans, in the mistaken belief that infectious threats can be kept out of the country by keeping certain people out. This can lead to calls to build walls, rather than support more effective, evidence-based policies. This was evident during the 2014 Ebola epidemic, when many politicians and pundits demanded the imposition of a travel ban, even though health experts cautioned that a ban would undermine efforts to fight the outbreak at its source in West Africa. ${ }^{104}$ Likewise, in 2018, anti-immigrant critics charged that a caravan of migrants heading toward the U.S. from Central America had to be stopped because they were bringing smallpox, leprosy, and other dangerous diseases into the country. ${ }^{105}$ Such false claims can mislead Americans into thinking that public health can be protected by keeping "them" out, rather than by vaccinating their own children. More generally, by locating health problems in "the other," xenophobia misdirects public health policy away from evidence-based interventions that address the complex social determinants of both communicable and non-communicable diseases.

\section{The Public CHARge REgUlations}

The potential of anti-immigration policies to harm both the health care system and public health is especially evident in the Trump Administration's proposed public charge regulations. As noted above, the INA has long deemed immigrants who are "likely to become a public charge" inadmissible to the United States. ${ }^{106}$ In the nineteenth and early twentieth centuries, this provision was widely used to keep out individuals who were considered undesirable on the basis of racial or class grounds. ${ }^{107}$ For example, in the 1930 s, the public charge provision was used to turn away Jewish refugees from the Holocaust. ${ }^{108}$

Currently, the provision does not apply to refugees, asylees, survivors of

104. Tom Frieden, CDC Director: Why I Don't Support a Travel Ban to Combat Ebola, CTRS. Disease Control \& Prevention: Our Global Voices (Oct. 13, 2014), https://blogs.cdc.gov/ global/2014/10/13/cdc-director-why-i-don't-support-a-travel-ban-to-combat-ebola-outbreak/ [https://perma.cc/6CUM-ULK3].

105. See Julia Belluz, Fox News Says the Migrant Caravan Will Bring Disease Outbreaks. That's Xenophobic Nonsense, Vox (Nov. 1, 2018, 12:06 PM), https://www.vox.com/science-andhealth/2018/11/1/18048332/migrant-caravan-fox-news-disease-smallpox-outbreaks-vaccinesxenophobia. [https://perma.cc/2VHV-94AQ]. The claim about smallpox was especially absurd, given that smallpox has been eradicated in nature. $I d$.

106. Immigration and Nationality Act $\S 212(a)(4), 8$ U.S.C. $\S 1182(a)(4)$ (2012).

107. See Lisa Sun-Hee Park, Criminalizing Immigrant Mothers: Public Charge, Health Care, and Welfare Reform, 37 InT'L J. Soc. FAM. 27, 43 (2011).

108. Barbara L. Bailin, The Influence of Anti-Semitism on United States Immigration Policy with Respect to German Jews During 1933-1939 (May 10, 2011) (unpublished M.A. thesis, City University of New York) (on file with City University of New York), https://academicworks. cuny.edu/cgi/viewcontent.cgi? article $=1261 \&$ context $=$ cc_etds_theses [https://perma.cc/CBD69DQA]. 
domestic violence and certain other exempt classes of immigrants. ${ }^{109}$ However, most immigrants who seek a visa or adjustment of status, usually to receive legal permanent residency status, have to prove they are not likely to become a public charge. ${ }^{110}$ In making its public charge determination, the INA requires the United States Citizenship and Immigration Service ("USCIS") to consider an immigrant's age, health, family status, resources and financial status, and education and skills. ${ }^{11}$

Since 1997, USCIS has not considered an immigrant's use of non-cash benefits, including Medicaid and CHIP, in making the public charge determination, except when the benefits were used for long-term care. ${ }^{112}$ The Trump Administration is seeking to change that, dramatically expanding the meaning and impact of the public charge determination.

Under proposed regulations that were published in the Federal Registrar on October 10, 2018, the term "public charge," would be defined to include immigrants who use more than fifteen percent of the federal poverty level of cash benefits, as well as specified non-cash benefits, including Medicaid, and Medicare Part D subsidies, as well as Supplemental Nutrition Assistance Program ("SNAP") or federal housing subsidies ${ }^{113}$ for more than twelve months within a thirty-six month period. ${ }^{114}$ (Although the regulations did not include CHIP in the definition of public charge, the Department of Homeland Security ("DHS") asked for comments about whether CHIP should be added. $)^{115}$ Thus an immigrant could be found "likely to become a public charge," and hence inadmissible, if USCIS found that he or she was likely to use Medicaid or Medicare Part D subsidies for twelve months out of thirty-six months subsequent to the adjustment of status. However, the regulations do not specify that the forward-looking determination

109. 8 U.S.C. $\S \S 1157(\mathrm{c})(3), 1182(\mathrm{a})(4)(\mathrm{E})(2012)$.

110. 8 U.S.C. § 1182(a)(4) (2012); see Em Puhl, et al., Immigration Legal Res. CTR., An Overview of Public Charge 1 (2018), https:/www.ilrc.org/sites/default/files/resources/ overview_of_public_charge-20181214.pdf [https://perma.cc/FS7V-QFPW] (stating that deportation on public charge grounds is possible, but only in very limited circumstances).

111. 8 U.S.C. $\S 1182(a)(4)(B)(i)(2012)$.

112. Inadmissibility and Deportability on Public Charge Grounds, 64 Fed. Reg. 28,676-677 (proposed May 26, 1999) (to be codified at 8 C.F.R. pts. 212, 237).

113. See Inadmissibility on Public Charge Grounds, 83 Fed. Reg. 51,114, 51,114 (proposed Oct. 10, 2018) (to be codified at 8 C.F.R. pts. 103, 212-14, 245, 248); see also Artiga et al., supra note 9 (discussing the public charge proposal and its impact on immigrants). Some Medicaid benefits, including benefits for foreign-born children of U.S. citizens, and benefits provided under the Individuals with Disabilities Education Act were exempted. See Inadmissibility on Public Charge Grounds, 83 Fed. Reg. at 51,170.

114. See Inadmissibility on Public Charge Grounds, 83 Fed. Reg. at 51,290 (discussing that under the proposed regulations, an immigrant who uses two or more of the listed benefits would be considered a public charge for using the benefits for fewer months, and in addition, that the use of the benefits for fewer months would trigger a public charge determination if the immigrant also received cash benefits).

115. Id. at 51,173 . 
is to be confined to the thirty-six months immediately following the adjustment of status, thus opening the possibility that an immigrant could be found likely to be a public charge if USCIS determined that the immigrant would use the listed benefits at any time in the future. ${ }^{116}$ Given the fact that as much as thirty percent of U.S. citizens receive some of the listed benefits, ${ }^{117}$ a very large number of immigrants will be vulnerable to the determination. ${ }^{18}$

The proposed regulations stress that the public determination must be made using the "totality of circumstances." immigrant is likely to be a public charge in the future, the regulations would require USCIS to treat the past use of the listed cash or non-cash benefits in the thirty-six months prior to application as a heavily weighted negative factor. ${ }^{120}$ Other negative factors include an income of less than $125 \%$ of the Federal Poverty Level, age under eighteen or over sixty-two, or having a medical condition that may lead to expensive treatment while lacking private health insurance. ${ }^{121}$

According to DHS, these regulations are necessary to enforce immigration law's goal of admitting only those who are "self-sufficient." 122 This goal, articulated in PRWORA, ${ }^{123}$ conflicts with public health's recognition that disease and disability are, for the most part, socially determined; and that no individual can be truly self-sufficient when it comes to health. ${ }^{124}$ Moreover, by labeling immigrants who use health benefits as "public charges," the regulations would effectively stigmatize and demean the over 66,000,000 individuals who are

116. Id. at 51,290 .

117. Id. at 51,185 .

118. Kate Woomer-Deters, The Proposed 'Public Charge' Rule: An Attack on IMMIGRANT AND WORKING FAMILIES 1 (N.C. Justice Ctr., 2018), https://www.ncjustice.org/wpcontent/uploads/2018/11/IRRP_Public-Charge-FactSheet-English-OCTOBER-2018.pdf [https://perma.cc/KC6N-VKXV].

119. Inadmissibility on Public Charge Grounds, 83 Fed. Reg. at 51,291. Many immigrants and mixed status families will also be adversely affected by other provisions in the proposal rule, including the proposal to treat income below $125 \%$ of the federal poverty level. $I d$. at 51,123 . Randy Capps et al., Gauging the Impact of DHS' Proposed Public-Charge Rule on U.S. IMMIGRATION 1 (Migration Policy Inst., 2018). The current discussion, however, focuses on the proposed regulation's treatment of non-cash benefits that relate to health.

120. CAPPS ET AL., supra note 119 , at $6,14$.

121. Inadmissibility on Public Charge Grounds, 83 Fed. Reg. at 51,290.

122. Id . at 51,118 ("The primary benefit of the proposed rule would be to help ensure that aliens who apply for admission to the United States, seek extension of stay or change of status, or apply for adjustment of status are self-sufficient").

123. 8 U.S.C. $\S 1601$ (2012).

124. See Samantha Artiga \& Elizabeth Hinton, Beyond Health Care: The Role of Social Determinants in Promoting Health and Health Equity, Henry J. KAISER FAM. Found. (May 10, 2018), https://www.kff.org/disparities-policy/issue-brief/beyond-health-care-the-role-of-socialdeterminants-in-promoting-health-and-health-equity/ [https://perma.cc/K6TN-R8K9]. See also ILLINGWORTH \& PARMET, supra note 10, at 115-32 (arguing that health is a public good). 
enrolled in Medicaid, ${ }^{125}$ and the over 13,000,000 Americans who receive Medicare D subsidies. ${ }^{126}$ The regulations would also exacerbate the stigma associated with disability by requiring USCIS to consider disability in the public charge determination. ${ }^{127}$ Although DHS promises that disability will not be the "sole factor" in that determination, ${ }^{128}$ by treating disability as a negative factor, in circumstances that go far beyond the commands of the INA, ${ }^{129}$ DHS is communicating the message that individuals with a disability are burdensome, public charges. This is a message that will undoubtedly rebound upon citizens with disabilities. It is also a message that is contrary to the one Congress sought to deliver in enacting the Rehabilitation Act of 1973 and the Americans with Disabilities Act. ${ }^{130}$

The regulations, like other immigrant-focused health policies, will also add needless complexity to our already complicated health care system. Under the proposal, the use of federal Medicaid, but not CHIP or state public health benefits, would constitute a heavily negative factor in the assessment of whether an immigrant was likely to be a public charge in the future. ${ }^{131}$ However, most

125. Ctrs. for Medicare \& Medicaid Servs., November 2018 Medicaid \& CHIP Enrollment Data Highlights, MediCARE.GOV, https:/www.medicaid.gov/medicaid/program-information/ medicaid-and-chip-enrollment-data/report-highlights/index.html [https://perma.cc/Y2BU-JQEL].

126. An Overview of the Medicare Part D Prescription Benefit, Henry J. KAISER FAm. Found. (Oct. 12, 2018), https://www.kff.org/medicare/fact-sheet/an-overview-of-the-medicarepart-d-prescription-drug-benefit/ [https://perma.cc/K9Z9-YB57].

127. Inadmissibility on Public Charge Grounds, 83 Fed. Reg. at 51,183.

128. Id.

129. The INA explicitly lists certain health and disability-related criteria. In addition to barring entry by individuals with a "communicable disease of public health significance," the statute bars admission by individuals who are not vaccinated with specified vaccines, or are determined "to have a physical or mental disorder and behavior associated with the disorder that may pose, or has posed, a threat to the property, safety, or welfare of the alien or others," or "to have had a physical or mental disorder and a history of behavior associated with the disorder, which behavior has posed a threat to the property, safety or welfare of the alien or others and which behavior is likely to recur or to lead to other harmful behavior," or are "determined. . to be a drug user or addict.." 8 U.S.C. $\S 1182(a)(1)(A)$ (2013). Notably, the Act does not list disability or other serious medical conditions as a ground for inadmissibility; rather, the disability and health-related bars are limited to situations in which the immigrant would pose a risk to the health or well-being of others. See, e.g., 8 C.F.R. $\S 212.4$ (2013); 8 C.F.R. $§ 212.7$ (2016). In contrast, by treating health conditions and disability as negative factors, even when they pose no risk to others, the proposed regulations would depart from those understandings, as well as from Congress's intention in limiting the reach of the health and disability-related bars.

130. See 42 U.S.C. $§ 12101$ (a) (2013) (stating Congress's findings in enacting the Americans with Disabilities Act); Sch. Bd. of Nassau Cty. v. Arline, 480 U.S. 273, 279 (1987) (discussing Congress's intent to move the nation past "archaic attitudes and laws" regarding disability in enacting the Rehabilitation Act of 1973).

131. See supra text accompanying note 115 . 
children who receive CHIP are covered through their state's Medicaid program. ${ }^{132}$ By treating all uses of "Medicaid" by immigrants as problematic, the public charge regulations may deter immigrants from using these even those programs that are otherwise excluded from the regulations. This may lead states to decide to disaggregate programs to reduce the chill. Doing so, of course, will add to state health care costs.

More importantly, the regulations will likely have a significant adverse impact on public health. Most directly, the regulations will increase the number of uninsured patients. By treating the past use of public health programs as a heavily weighted negative factor, and defining someone who uses health benefits as a public charge, the regulations are expected to deter many immigrants, and citizens in mixed-status families, from accessing health benefits to which they are legally entitled. ${ }^{133}$ The Henry J. Kaiser Family Foundation, for example, estimates that the regulations will cause 2.1 to 4.9 million enrollees to leave Medicaid and CHIP. ${ }^{134}$ The California Health Care Foundation estimates that 700,000 to 1.7 million children who are in need of medical attention will disenroll from Medicaid or CHIP. ${ }^{135}$ Importantly, even many immigrants and citizens who are not subject to the public charge determination are expected to dis-enroll from Medicaid and CHIP, as past experience with laws limiting coverage for immigrants suggest that the chill can extend far beyond those who are directly affected. ${ }^{136}$ This seems especially likely given the current climate of fear.

As noted above, immigrants' loss of health coverage can have substantial negative impacts on health care providers. ${ }^{137}$ Safety-net providers in communities with large immigrant populations will likely see significant increases in uncompensated care, adding financial strains to already burdened safety-net providers. ${ }^{138}$ According to a report by Manatt Health, hospitals are at risk of losing $\$ 17$ billion a year. ${ }^{139}$ At the same time, hospitals will face increases in uncompensated care, as immigrants are forced to rely increasingly on emergency care. ${ }^{140}$ Ironically, the regulations may exacerbate this problem because the use of Medicaid for emergency medical conditions will not count in the public charge

132. MANN ET AL., supra note 90, at 4 .

133. Id.

134. Artiga et al., supra note 9. Although the proposal does include CHIP in the definition of public charge, more than half of the children whose health coverage is funded by CHIP are enrolled in state Medicaid programs, and many families do not know whether their coverage is through CHIP or Medicaid. See MANN ET AL., supra note 90, at 7.

135. Leah Zallman \& Karen Finnegan, Changing Public Charge Immigration Rules: The Potential Impact on Children Who Need Care, Cal. Health Care Found. (Oct. 23, 2018), https://www.chcf.org/publication/changing-public-charge-immigration-rules/ [https://perma.cc/G3DW-UJ5K].

136. MANN ET AL., supra note 90, at 11.

137. See supra text accompanying notes 90-94.

138. MANN ET AL., supra note 90, at 4.

139. Id. at 5 (based on 2016 revenues).

140. Id. at 4 . 
determination. ${ }^{141}$ Thus immigrants will have a strong incentive to avoid receiving Medicaid coverage unless and until a condition becomes emergent. This incentive will likely be strengthened by the fact the regulations will also treat the presence of medical conditions in the absence of private insurance as a negative factor. ${ }^{142}$ As a result, immigrants who are uninsured, or who receive state insurance benefits, may feel that it is unwise to see physicians or have diagnostic tests, lest they be found to have a medical condition that might disqualify them from receiving permanent residency status. In addition, by treating other non-cash benefits, including SNAP and housing support, as a public charge, the regulations will reduce immigrants' use of nutritional and housing programs that can be important positive social determinants of health. ${ }^{143}$

The health impacts of these regulations, as well as other immigration laws that relate to health, will not be limited to noncitizens. Eighteen million American citizen children have at least one immigrant parent. ${ }^{144}$ These children will inevitably be affected, not only because of the chilling effect that may lead parents to dis-enroll citizen children from health programs, but because increased parental coverage is associated with increases in pediatric primary care in lowincome families. ${ }^{145}$ Moreover, children will feel the effects if their parents lose access to health coverage and forgo medical care. American citizen children will also feel the impact if their parents forgo SNAP or housing subsidies. Food and housing, after all, affect everyone in a household. In addition, the health of households affects the health of their communities. When children can't go to school because they or their parents are sick, when workers can't be productive because they're forgoing basic health care, communities as a whole suffer. Thus, in the name of promoting self-sufficiency among immigrants, the regulations will

141. Inadmissibility on Public Charge Grounds, 83 Fed. Reg. 51,114, 51,290 (proposed Oct. 10, 2018) (to be codified at 8 C.F.R. pts. 103, 212-14, 245, 248).

142. Although the regulations do not view receipt of ACA subsidies as rendering someone a public charge, the provisions in the regulations relating to medical conditions seem broader, and treat the presence of a medical condition in the absence of private insurance, as a highly weighted negative factor in the public charge determination. Inadmissibility on Public Charge Grounds, 83 Fed. Reg. at 51,182. This would seem to suggest that an immigrant who receives ACA premium tax credits, CHIP, or state benefits, and is diagnosed with a pre-existing condition, might as a result be found likely be found to be a public charge. If so, the regulations will disincentivize immigrants from enrolling even in those programs that are not included in the definition of public charge.

143. On SNAP as a positive social determinant of health, see Nancy E. Adler et al., Addressing Social Determinants of Health and Health Inequalities, 316 J. Am. Med. Ass'N 1641, 1641 (2016). On the relationship between housing affordability and health, see Megan Sandel \& Matthew Desmond, Investing in Housing for Health Improves Both Mission and Margin, 318 J. AM. MED. Ass'N 2291, 2291 (2017); B. Cameron Webb \& Dayna Bowen Matthew, Housing: A Case for the Medicalization of Poverty, 46 J.L. MED. \& ETHICs 588, 591, 593 (2018).

144. Children in U.S. Immigrant Families, supra note 89.

145. Maya Venkataramani et al., Spillover Effect of Adult Medicaid Expansion on Children's Use of Preventive Services, 140 PEDIATRICS 1, 6 (2017), http://pediatrics.aappublications.org/ content/pediatrics/140/6/e20170953.full.pdf [https://perma.cc/6MXP-P7GM]. 
threaten the health of all.

\section{SOLIDARITY FOR HEALTH}

What can we learn about health law from its relationship with immigration policy? Most obviously, we see from the exclusions and the insistence on selfsufficiency the strong strains of individualism and individual responsibility that run through American health policy, and have helped to mark other battles over Medicaid, Medicare, and even the ACA. Ambivalent about the idea that health care is right, reluctant to see diseases as socially determined, we often feel the need to draw lines, limit eligibility, and blame people for their own illnesses. In this task, immigration policy, especially exclusionist immigration policy, presents a handy tool. Immigrants are easy scapegoats. If lines have to be drawn, they can easily be drawn around noncitizens who cannot vote and are often members of racial or ethnic minorities. And if citizens can bar and blame noncitizens, they can feel confident that the health care system is only for those who are deserving.

Yet, the story is more nuanced. Immigration policy adds to the complexity of and contradictions within our health care system precisely because many exclusions are partially mitigated by exceptions; and punitive measures are often counter-balanced by more inclusive, and supportive policies. These exceptions to the exclusions that add to health law's complexity suggest that individualism, exclusion, and xenophobia are not the only, or even the dominant chords at the intersection between health and immigration. There are also strong themes of inclusion, compassion, and even solidarity. ${ }^{146}$

This, I think, gets us to the gist of the tensions at the juncture between immigration and health law. Perhaps more than any other field, health law deals with human vulnerability: our illnesses, our weaknesses, and ultimately our mortality. As patients, we literally and metaphorically expose ourselves to others; we become intimate and vulnerable.

To whom shall we expose ourselves? To whose vulnerabilities shall we respond? As Ruud ter Meulen explains, the concept of solidarity refers to a willingness to act for others out of a sense of identification with them. ${ }^{147}$ Solidarity underpins a willingness to carry costs for others that goes beyond simple, short term self-interest. ${ }^{148}$ I care for the health of others not because I believe that doing so will benefit me (though at times it will), or even because doing so is just (though it may well be). I do so because I recognize my own vulnerabilities in their predicament.

Solidarity is often said to underpin the social welfare state, including national

146. See supra notes 63-76 and accompanying text; see also ILlingWORTH \& PARMET, supra note 10, at 190-97 (describing the U.S. response to the Ebola outbreak in West Africa as evincing solidarity).

147. Ruud ter Meulen, Solidarity and Justice in Health and Social Care 4 (2017).

148. Barbara Prainsack \& Alena Buyx, Solidarity in Contemporary Bioethics-Towards a New Approach, 26 Bioethics 343, 347 (2012). 
health care systems. ${ }^{149}$ We see it in the United Kingdom's National Health Service, and in the Canada Health Act. But it is also present, albeit to a lesser extent, in Medicare, Medicaid, and the ACA.

Solidarity, however, can be and often is exclusionary. It may also adhere more easily to those who appear similar, or who share a demographic identity. Relatedly, some have theorized that the regulation of immigration and the maintenance of borders may serve to abet the formation solidarity, ${ }^{150}$ while inclusion and heterogeneity may weaken the solidarity that is necessary for the maintenance of strong social welfare programs. ${ }^{151}$ Perhaps for this reason, as noted above, even the most robust national health programs exclude certain newcomers. Moreover, the most generous social welfare states tend to be in relatively homogenous countries; and social welfare programs in these states have faced new challenges as globalization and migration have threatened national homogeneity. ${ }^{152}$

Solidarity, however, need not rely on either borders or demographic identities. It can also cohere around mutual goals and experiences, common causes, shared vulnerabilities and caregiving. ${ }^{153}$ As Iris Young explains, solidarity can arise among people who "dwell together." 154 Bruce Jennings adds that solidarity can develop when people share relationships of "structural interdependence." 155 And no realm creates more opportunities for shared experiences and interdependencies across immigration statuses than health. Immigrant caregivers take care of citizen patients in their most vulnerable hours, while citizen providers care for their immigrant patients in their times of need. ${ }^{156}$ Immigrant and native-born share overcrowded emergency departments, breathe the same polluted air, and suffer from the same disease outbreaks. They experience the same social determinants, and the health of each affects the health of the other. This commonality of experience and interdependency with respect to health creates shared interests and mutual vulnerabilities, opening the door to

149. See Illingworth \& PARmet, supra note 10, at 174; see also Lisa Eckenwiler et al., Global Solidarity, Migration and Global Health Inequity, 26 Bioethics 382, 383 (2012).

150. See Illingworth \& PARMet, supra note 10, at 175-76. Hiroshi Motomura writes that a "persuasive" argument for immigration laws and borders is that they can reinforce "civic solidarity." Hiroshi Motomura, Who Belongs?: Immigration Outside the Law and the Idea of Americans in Waiting, 2 U.C. Irvine L. Rev 359, 365 (2012).

151. See, e.g., Paul Collier, Exodus: How Migration is Changing our World 85 (2013).

152. See David Abraham, Recognizing the Problem of Solidarity: Immigration in the PostWelfare State, 55 WAYNE L. REV. 1641, 1645 (2009).

153. Prainsack \& Buyx, supra note 148 , at 346-48.

154. IRIS MARION YOUnG, InClusion AND DEMOCRACY 197 (2000). For a further discussion, see ILLINGWORTH \& PARMET, supra note 10, at 182-89.

155. Bruce Jennings, Solidarity and Care as Relational Practices, 32 Bioethics 553, 554 (2018).

156. For a discussion of how the inclusion of migrant workers in the health care workforce create opportunities for solidarity, see Eckenwiler et al., supra note 149, at 385-87. 
a solidarity that need not be defined by demographic identities or citizenship status. ${ }^{157}$

Despite the current climate of ethno-nationalism, we see signs of this occurring, not only in the exceptions to the exclusionary policies, and the policies that provide for the health of newcomers, but also in the demonstrations by doctors against the travel ban, ${ }^{158}$ the statements of physician groups protesting family separation, ${ }^{159}$ and the innumerable non-governmental organizations that are fighting for better health for all members of their community. ${ }^{160}$ Thus, solidarity can and has been forming around health. From there it can potentially extend to other domains, challenging structures of social injustice. Bruce Jennings explains, "Solidarity begins with the recognition of reciprocal and symbiotic interdependence among members of a moral community and then intervenes ininterrupts-an ongoing community when it is unjustly exclusionary and refuses to recognize the moral standing of some within it." 161 Or, to put it another way, the solidarity that forms in health can force us to see and then demand a wider recognition of each other's humanity.

Perhaps this is why the battles over health and immigration are so contentious. The laws and policies that lie at the intersection of immigration and health are not simply about the health of immigrants. Rather, the barriers that are imposed on the health of immigrants are structures designed to thwart the formation of solidarity and the rejection of intolerance. And the exceptions to the exclusions and the resistance to those barriers are reminders of why we have health care systems and laws to support them: because we are human.

157. IllingWORTh \& PARMet, supra note 10, at 177-89.

158. Felice J. Freyer, In White Coats, Doctors Join Copley Protest, Boston Globe (Jan. 29, 2017), https://www.bostonglobe.com/metro/2017/01/29/white-coats-doctors-join-copleyprotest/H6qUBK5rfJpsE6S2XlglEK/story.html [https://perma.cc/BJ42-QHPA].

159. Biggest U.S. Doctors Group Condemns Family Separation Policy, Politico (June 20, 2018, 12:07 PM), https://www.politico.com/story/2018/06/20/american-medical-associationfamily-separation-policy-655677 [https://perma.cc/9PEG-GALH].

160. Id., see, e.g., ILLINGWORTH \& PARMET, supra note 10, at 182.

161. Jennings, supra note 155 , at 557. 